\title{
Effect of Seed Rate on Yield Components and Grain Yield of Ridge Sown Wheat Varieties
}

\section{Javed Iqbal $^{1}$, Ali Zohaib ${ }^{1 *}$, Muzzammil Hussain ${ }^{1}$, Adnan Bashir ${ }^{1}$, Muhammad Hamza $^{2}$,Wardah Muzaffer ${ }^{3}$, Muhammad Tahir Latif ${ }^{1}$ and Naeem Faisal $^{1}$}

\section{${ }^{1}$ Adaptive Research Farm, Gujranwala 52200, Pakistan; ${ }^{2}$ Department of Agronomy, University of Agriculture, Faisalabad 38040, Pakistan; ${ }^{3}$ Sugarcane Research Institute, Ayub Agricultural Research Institute, Faisalabad 38000, Pakistan.}

Abstract | Wheat productivity could be improved by ridge sowing with optimized seed rate for different varieties. This 3-years study was conducted to determine the optimum seed rate for different varieties of ridge sown wheat for better yield and related components. Wheat varieties (Faisalabad-08, Punjab-11 and Galaxy-13) were sown on ridges using two different seed rates (125 and $\left.150 \mathrm{~kg} \mathrm{ha}^{-1}\right)$. Increase in seed rate improved the emergence (plants per $\mathrm{m}^{2}$ ), number of productive tillers per $\mathrm{m}^{2}$ and grain yield (3-7\%) of all wheat varieties although productive tillers per plant, number of grains per spike and 1000-grain weight was decreased. Faislabad-08 performed better regarding grain yield and related components among all varieties. Seed rate and varieties did not interact significantly for studied traits. Correlation analysis revealed that grain yield was positively correlated with number of productive tillers per $\mathrm{m}^{2}$ during all years and grain weight during first year; while, negatively correlated with number of grains per spike during second year indicating that increase in grain yield was associated mainly with increase in number of productive tillers per unit area in response to seed rate. In conclusion, increase in seed rate improved the grain yield of ridge sown wheat by enhancing the number of productive tillers per unit area and could be exploited to improve the wheat productivity.

Received | February 06, 2020; Accepted | March 25, 2020; Published | July 26, 2020

*Correspondence | Ali Zohaib, Adaptive Research Farm, Gujranwala 52200, Pakistan; Email: alizohaib208@gmail.com

Citation | Iqbal, J., A. Zohaib, M. Hussain, A. Bashir, M. Hamza, W. Muzaffer, M.T. Latif and N. Faisal. 2020. Effect of seed rate on yield components and grain yield of ridge sown wheat varieties. Pakistan Journal of Agricultural Research, 33(3): 508-515.

DOI | http://dx.doi.org/10.17582/journal.pjar/2020/33.3.508.515

Keywords | Correlation, Grain yield, Ridge sowing, Seed rate, Wheat

\section{Introduction}

$\mathrm{W}_{\mathrm{f}}$ heat (Triticum aestivum L.) is the major staple food cereal crop in most of the countries and cultivated in wide range of environments. Its yield is greatly influenced by crop management factors. Among several crop management factors sowing method, seeding rate and selection of appropriate genotype have prime role in affecting wheat productivity (Chauhdary et al., 2016; Isidro-Sánchez et al., 2017). Appropriate sowing method not only aids in establishment of proper crop stand but also improves the conversion of light energy by balancing inter-plant competition thereby improving the crop yield (Ali et al., 2012; Ehsanullah et al., 2017; Rasool et al., 2017). Hence such cultivation system and/or sowing method should be adopted which could improve the soil properties such as moisture, temperature and root penetration in order to improve the plant growth and productivity (Krause et al.,2009). Ridge sowing of wheat improves the crop yield and water saving by improving the plant tillering capacity, soil moisture content and nutrient availability (Hussain et al., 2018). However, ridge sowing often 
ensues in poor stand establishment (Hussain et al., 2015) which could become the limiting factor. Hence, optimization of seed rate with appropriate variety is crucial for maintaining proper plant population to acquire better crop yield from ridge sown wheat (Chauhdary et al., 2016).

Optimum seed rate is an important factor which regulates the capability of crop plants to capture the available resources (Lloveras et al., 2004). Seed rate determines the planting density which in turn influences the crop growth, nutrient uptake, tillering capacity, number and weight of grains, and ultimately grain yield due to inter-plant competition (Stephen et al., 2005; Nakano and Morita, 2009; Zohaib et al., 2018). Generally, the availability of environmental resources to plants is enhanced at optimum seed rate (Arduini et al., 2006). However, less seed rate results in low plant population which causes greater tiller production but decreased number of spikes per unit area due to inter-tiller competition for plant available resources (Ozturk et al., 2006; Tapley et al., 2013). On the other hand, use of high seed rate with narrow row spacing has been observed to enhance grain yield of winter wheat (Joseph et al., 1985). However, high plant density due to high seed rate don't always increase grain yield because of high inter-plant competition, and availability of nitrogen and soil moisture (Fischer et al., 1976; Read and Warder, 1982; Park et al., 2003). Previous studies have reported inconsistent yield increase in response to increase in seed rate of wheat (Staggenborg et al., 2003; Otteson et al., 2007; Kabir et al., 2009).

A differential behavior exists among different genotypes of wheat pertaining to growth behavior and grain yield (Khan et al., 2002; Zecevic et al., 2014). Moreover, different varieties of same species respond differently to applied inputs regarding growth and yield formation indicating that selection of appropriate variety with specific set of management practices is required (Nizamani et al., 2014; Belete et al., 2018Zohaib et al., 2019). Wheat varieties differ in their growth habit and tillering capacity which necessitates the maintenance of specific plant density for specific variety. Hence, optimization of seed rate with variety of wheat is essential to obtain optimum plant density for maximum grain yield and potential benefits (Ciha, 1983; Stephen et al., 2005). Khan et al. (2002) reported that grain yield of cultivars Inqlab-91 and Bakhtawar-92 increased with increase in seed rate up to $150 \mathrm{~kg} \mathrm{ha}^{-1}$; however, the performance of Bakhtawar-92 was better than Inqlab-91 in response to increase in seed rate. Similarly, Nizamani et al. (2014) reported that variety Sarsabz produced maximum grain yield at $150 \mathrm{~kg}$ seed $\mathrm{ha}^{-1}$ while Kiran-95 and TD-1 at $125 \mathrm{~kg}$ seed ha ${ }^{-1}$ indicating the differential response of varieties to different seed rate.

Ridge sowing affects the wheat productivity but poor crop stand establishment could become the limiting factor. Optimization of seed rate with different varieties is crucial for improving productivity of ridge sown wheat. It was hypothesized that increase in seed rate will improve the productivity of ridge sown wheat by improving the number of tillers per unit area through improved stand establishment. The present study was conducted to ascertain the effect of seed rate on yield components and grain yield of different ridge sown wheat varieties.

\section{Materials and Methods}

\section{Experimental details}

Study was performed to determine the effect of seed rate on yield components and grain yield of different wheat varieties at Adaptive Research Farm, Gujranwala, Pakistan (32 $12^{\prime} 15^{\prime \prime} \mathrm{N} 74^{\circ} 13^{\prime} 48^{\prime \prime} \mathrm{E} 227$ $\mathrm{m}$ above sea level) during 2014-15 to 2016-17. Soil samples were collected from the field before sowing the crop from a depth of 0-30 $\mathrm{cm}$ for analysis of physico-chemical properties. The collected samples were air dried, sieved ( $2 \mathrm{~mm}$ pore size) after grinding and submitted to Soil and Water Testing Laboratory, Gujranwala for analysis. The soil was heavy loam and medium in soil fertility status. The physicochemical properties of soil are given in Table 1 . The experiment was carried out using randomized complete block design with factorial arrangement and three replications. The net plot size was $19 \times 9 \mathrm{~m}^{2}$. The treatments included two different seed rates (125 and $150 \mathrm{~kg} \mathrm{ha}^{-1}$ ) and three varieties (Faisalabad-08, Punjab-11 and Galaxy-13) of wheat.

\section{Crophusbandry}

The crop was sown in last week of November during all the years. The varieties and seed rate was used according to the treatments. Sowing was accomplished by broadcasting the seed followed by formation of ridges using potato ridger. Recommended dose of NPK (115-85-62 $\mathrm{kg} \mathrm{ha}{ }^{-1}$ ) was applied using urea $(46 \% \mathrm{~N})$, diammonium phosphate (DAP) (18\% 
$\left.\mathrm{N}, 46 \% \mathrm{P}_{2} \mathrm{O}_{5}\right)$ and sulphate of potash (SOP) $(50 \%$ $\mathrm{K}_{2} \mathrm{O}$ ). Full $\mathrm{P}, \mathrm{K}$ and half $\mathrm{N}$ was applied as basal dose and remaining half dose of $\mathrm{N}$ was applied with first irrigation. Irrigations were applied according to soil and weather conditions and in total 2 irrigations were applied during each year. Local recommendations were followed for plant protection measures. The crop was harvested and threshed manually during last week of April during each year. Meteorological data during growing periods of wheat are presented in Table 2 .

Table 1: Physico-chemical characteristics of experimental soil.

$\begin{array}{lll}\text { Characteristics } & \text { Value } & \text { Unit } \\ \text { Soil type } & \text { Heavy loam } & - \\ \text { pH } & 8.0 & - \\ \text { EC } & 1.4 & \mathrm{dSm}^{-1} \\ \text { Organic matter } & 0.78 & \% \\ \text { Total Nitrogen } & 0.047 & \% \\ \text { Available phosphorus } & 10.4 & \mathrm{ppm} \\ \text { Available potash } & 130 & \mathrm{ppm}\end{array}$

\section{Observations}

Data regarding emergence count (plants per $\mathrm{m}^{2}$ ) was recorded after the completion of emergence by counting plants from randomly selected areas in all replications and averaged. Yield and yield attributes were recorded at harvest maturity. Number of productive tillers per $\mathrm{m}^{2}$ was recorded by counting the productive tillers from randomly selected areas in each replication and averaged. Average number of tillers per plant was determined by dividing the number of tillers $\mathrm{m}^{-2}$ by number of plants per $\mathrm{m}^{-2}$. Number of grains per spike was determined by randomly collecting and manually threshing the five spikes from each replication followed by counting the grains from each replication and averaging. The 1000-grain weight was determined by counting thousand grains from each replication, weighing with electric weight balance and averaging. Grain yield was recorded by manually harvesting and threshing the wheat from selected one $\mathrm{m}^{2}$ area in each replication. The yield obtained was averaged and expressed as $\mathrm{tha}^{-1}$.

\section{Statistical analyses}

The normality of data were checked by using scatter plot technique. The data were found normal and analyzed separately for each year because the year effect was found significant for studied traits. Data were analyzed statistically by Fisher's analysis of variance (ANOVA) technique (Steel et al., 1997) and least significance difference (LSD) test at 5\% probability was used for comparing the treatments' means. Pearson's coefficients were calculated to determine the correlation between yield attributes (number of productive tillers per $\mathrm{m}^{2}$, number of grains per spike and 1000-grain weight) and grain yield as well as among yield attributes of wheat to determine the association between yield attributes and grain yield in response to seed rate and varieties.

\section{Results and Discussion}

Seed rate significantly affected the emergence, number of productive tillers and grains per spike, and 1000-grain weight of ridge sown wheat during all years, and average number of tillers per plant during 2014-15 and 2016-17. Varieties significantly differed in emergence and number of grains per spike during 2014-15, number of tillers per $\mathrm{m}^{2}$, average number of tillers per plant (and 1000-grain weight during all years, and grain yield during 2014-15 and 2015-16. However, interaction between seed rate and varieties was non-significant for all studied traits during all years (Tables 3 and 4).

Across varieties, the higher seed rate $\left(150 \mathrm{~kg} \mathrm{ha}^{-1}\right)$ gave higher emergence count and produced more number of productive tillers per $\mathrm{m}^{2}$ during all years (Table 3). Conversely, average number of tillers per plant, number of grains per spike and 1000-grain weight were greater in response to lower seed rate $\left(125 \mathrm{~kg} \mathrm{ha}^{-1}\right)$ as compared to higher seed rate (150 $\mathrm{kg} \mathrm{ha} \mathrm{h}^{-1}$ ) during all years except 1000-grain weight during 2014-15 when the results were vice versa (Table 4). The grain yield was however increased (3$7 \%)$ by increasing the seed rate, as compared to lower seed rate, during all years (Table 4). Across seed rate, Galaxy-13 exhibited higher emergence followed by Faisalabad-08; however, higher number of tillers per $\mathrm{m}^{2}$ and average number of tillers per plant was recorded by Faisalabad-08, during all the years (Table 3). Maximum number of grains per spike was produced by Faisalabad-08 during 2014-15 while statistically similar results were produced by all varieties during 2015-16 and 2016-17. The 1000-grain weight and grain yield of Faisalabad-08 was the greatest among all varieties during all years. Grain yield of Faisalabad-08 was followed by Galaxy-13 during 2014-15 and 2015-16, and Punjab-11 during 2016-17 (Table 4). 
Table 2: Meteorological conditions during wheat growing seasons.

\begin{tabular}{|c|c|c|c|c|c|c|c|c|c|c|c|c|}
\hline \multirow[t]{3}{*}{ Month } & \multirow{2}{*}{\multicolumn{3}{|c|}{$\begin{array}{l}\text { Total Rainfall } \\
(\mathrm{mm})\end{array}$}} & \multicolumn{9}{|c|}{ Temperature $\left({ }^{\circ} \mathrm{C}\right)$} \\
\hline & & & & \multicolumn{3}{|c|}{ Monthly maximum } & \multicolumn{3}{|c|}{ Monthly minimum } & \multicolumn{3}{|c|}{ Daily mean } \\
\hline & 2014-15 & 2015-16 & 2016-17 & 2014-15 & 2015-16 & 2016-17 & 2014-15 & 2015-16 & 2016-17 & 2014-15 & $2015-16$ & 2016- \\
\hline November & 2.4 & 0.0 & 3.0 & 26.0 & 25.5 & 25.3 & 14.0 & 12.8 & 11.8 & 20.0 & 19.2 & 18.6 \\
\hline December & 0.0 & 1.2 & 0.0 & 17.0 & 21.2 & 23.2 & 5.0 & 6.3 & 6.3 & 11.0 & 13.8 & 14.8 \\
\hline January & 8.4 & 18.7 & 19.0 & 15.1 & 14.3 & 14.0 & 4.2 & 3.5 & 3.9 & 9.7 & 8.9 & 9.0 \\
\hline February & 36.0 & 14.0 & 8.0 & 20.0 & 21.3 & 23.0 & 8.1 & 9.0 & 9.2 & 14.1 & 15.2 & 16.1 \\
\hline March & 66.2 & 51.4 & 64.0 & 24.0 & 26.1 & 28.5 & 14.4 & 14.3 & 13.8 & 19.2 & 20.2 & 21.2 \\
\hline April & 13.3 & 40.3 & 6.0 & 34.2 & 34.3 & 37.2 & 18.2 & 18.9 & 20.2 & 26.2 & 26.6 & 28.7 \\
\hline
\end{tabular}

Source: Meteorological Department, Punjab.

Table 3: Effect of different seed rates on emergence, number of productive tillers per $m^{2}$ and number of tillers per plant of ridge sown wheat varieties.

\begin{tabular}{|c|c|c|c|c|c|c|c|c|c|}
\hline \multirow[t]{2}{*}{ Treatments } & \multicolumn{3}{|c|}{ Emergence count (plants $\mathbf{m}^{-2}$ ) } & \multicolumn{3}{|c|}{ No. of productive tillers per $\mathbf{m}^{2}$} & \multicolumn{3}{|c|}{ Number of tillers per plant } \\
\hline & 2014-15 & 2015-16 & 2016-17 & 2014-15 & 2015-16 & 2016-17 & 2014-15 & 2015-16 & 2016-17 \\
\hline \multicolumn{10}{|c|}{ Seed rate $(\mathrm{S})\left(\mathrm{kg} \mathrm{ha}^{-1}\right)$} \\
\hline 125 & $169.0 \mathrm{~b}$ & $175.1 \mathrm{~b}$ & $167.1 \mathrm{~b}$ & $324.0 \mathrm{~b}$ & $312.4 \mathrm{~b}$ & $317.8 \mathrm{~b}$ & $1.92 \mathrm{a}$ & $1.78 \mathrm{a}$ & $1.90 \mathrm{a}$ \\
\hline 150 & $184.8 \mathrm{a}$ & $189.7 \mathrm{a}$ & $182.9 \mathrm{a}$ & $344.3 \mathrm{a}$ & $336.3 \mathrm{a}$ & $344.3 \mathrm{a}$ & $1.87 \mathrm{~b}$ & $1.78 \mathrm{a}$ & $1.85 \mathrm{~b}$ \\
\hline \multicolumn{10}{|l|}{ Varieties (V) } \\
\hline Faisalabad-08 & $173.3 \mathrm{~b}$ & $181.8 \mathrm{a}$ & $173.5 \mathrm{a}$ & $350.2 \mathrm{a}$ & $333.3 \mathrm{a}$ & $341.5 \mathrm{a}$ & $2.02 \mathrm{a}$ & $1.83 \mathrm{a}$ & $1.95 \mathrm{a}$ \\
\hline Punjab-11 & $170.2 \mathrm{~b}$ & $181.8 \mathrm{a}$ & $175.0 \mathrm{a}$ & $317.3 \mathrm{c}$ & $317.0 \mathrm{~b}$ & $323.0 \mathrm{~b}$ & $1.87 \mathrm{~b}$ & $1.74 \mathrm{ab}$ & $1.83 \mathrm{~b}$ \\
\hline Galaxy-13 & $187.2 \mathrm{a}$ & $183.5 \mathrm{a}$ & $176.5 \mathrm{a}$ & $335.0 \mathrm{~b}$ & $322.8 \mathrm{~b}$ & $328.7 \mathrm{~b}$ & $1.79 \mathrm{c}$ & $1.76 \mathrm{~b}$ & $1.85 \mathrm{~b}$ \\
\hline \multicolumn{10}{|c|}{ Source of variation $(\mathrm{Pr}>\mathrm{F})$} \\
\hline S & 0.003 & 0.002 & 0.001 & 0.001 & $<0.001$ & $<0.001$ & 0.043 & 0.752 & 0.044 \\
\hline V & 0.014 & 0.903 & 0.516 & $<0.001$ & 0.005 & 0.004 & $<0.001$ & 0.045 & 0.004 \\
\hline $\mathrm{S} \times \mathrm{V}$ & 0.730 & 0.937 & 0.947 & 0.481 & 0.674 & 0.932 & 0.985 & 0.539 & 0.940 \\
\hline
\end{tabular}

Means in a column having same letters don't differ significantly at $P<0.05$

Table 4: Effect of different seed rates on yield related attributes and grain yield of ridge sown wheat varieties.

\begin{tabular}{|c|c|c|c|c|c|c|c|c|c|}
\hline \multirow[t]{2}{*}{ Treatments } & \multicolumn{3}{|c|}{ Number of grains per spike } & \multicolumn{3}{|c|}{ 1000-grain weight (g) } & \multicolumn{3}{|c|}{ Grain yield $\left(\mathrm{t} \mathrm{ha}^{-1}\right)$} \\
\hline & 2014-15 & 2015-16 & 2016-17 & 2014-15 & $2015-16$ & 2016-17 & 2014-15 & 2015-16 & 2016-17 \\
\hline \multicolumn{10}{|c|}{ Seed rate $\left(\mathrm{kg} \mathrm{ha}^{-1}\right)$} \\
\hline $125-0$ & $40.1 \mathrm{a}$ & $40.0 \mathrm{a}$ & $40.9 \mathrm{a}$ & $35.67 \mathrm{~b}$ & $38.58 \mathrm{a}$ & $37.68 \mathrm{a}$ & $3.07 \mathrm{~b}$ & $4.01 \mathrm{~b}$ & $3.96 \mathrm{~b}$ \\
\hline 150 & $38.6 \mathrm{~b}$ & $38.7 \mathrm{~b}$ & $38.9 \mathrm{~b}$ & $36.17 \mathrm{a}$ & $37.03 \mathrm{~b}$ & $36.66 \mathrm{~b}$ & $3.28 \mathrm{a}$ & $4.13 \mathrm{a}$ & $4.10 \mathrm{a}$ \\
\hline \multicolumn{10}{|l|}{ Varieties } \\
\hline Faisalabad- 08 & $40.8 \mathrm{a}$ & $39.2 \mathrm{a}$ & $39.8 \mathrm{a}$ & $36.79 \mathrm{a}$ & $39.01 \mathrm{a}$ & $38.59 \mathrm{a}$ & $3.49 \mathrm{a}$ & $4.10 \mathrm{a}$ & $4.30 \mathrm{a}$ \\
\hline Punjab-11 & $38.5 \mathrm{~b}$ & $39.5 \mathrm{a}$ & $40.6 \mathrm{a}$ & $35.37 \mathrm{~b}$ & $37.33 \mathrm{~b}$ & $36.57 \mathrm{~b}$ & $2.94 \mathrm{c}$ & $4.04 \mathrm{a}$ & $3.92 \mathrm{~b}$ \\
\hline Galaxy-13 & $38.7 \mathrm{~b}$ & $39.4 \mathrm{a}$ & $39.3 \mathrm{a}$ & $35.60 \mathrm{~b}$ & $37.07 \mathrm{~b}$ & $36.35 \mathrm{~b}$ & $3.09 \mathrm{~b}$ & $4.07 \mathrm{a}$ & $3.88 \mathrm{~b}$ \\
\hline \multicolumn{10}{|c|}{ Source of variation $(\operatorname{Pr}>F)$} \\
\hline S & 0.011 & 0.029 & 0.005 & $<0.001$ & 0.001 & 0.018 & 0.001 & 0.021 & 0.037 \\
\hline V & 0.007 & 0.855 & 0.231 & $<0.001$ & 0.002 & 0.001 & $<0.001$ & 0.667 & 0.001 \\
\hline $\mathrm{S} \times \mathrm{V}$ & 0.811 & 0.696 & 0.340 & 0.365 & 0.147 & 0.443 & 0.499 & 0.689 & 0.615 \\
\hline
\end{tabular}

Means in a column having same letters don't differ significantly at $P<0.05$

Table 5: Pearson's coefficients of correlation between grain yield and related attributes of ridge sown wheat varieties under the influence of different seed rates.

Variables Grain yield $\left(\mathrm{t} \mathrm{ha}^{-1}\right) \quad$ No. of tillers per $\mathrm{m}^{2} \quad$ No. of grains per spike $\quad$ 1000-grain weight $(\mathrm{g})$ 2014-15 2015-16 2016-17 2014-15 2015-16 2016-17 2014-15 2015-16 2016-17 2014-15 2015-16 2016-17

Grain yield $\left(\mathrm{t} \mathrm{ha} \mathrm{a}^{-1}\right) \quad 1 \quad 1 \quad 1$

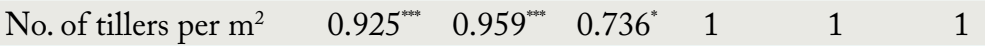

$\begin{array}{lllllllll}\text { No. of grains per spike } & 0.458^{\text {ns }} & -0.829^{* * *} & -0.230^{\text {ns }} & 0.182^{\text {ns }} & -0.885^{* *} & -0.788^{*} & 1 & 1\end{array}$

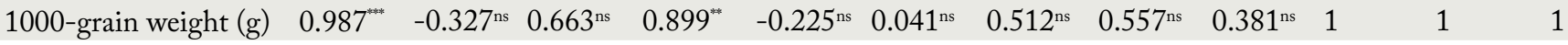

$P<0.01 ; " \mathrm{P}<0.05 ; " \mathrm{P}<0.1$; ${ }^{\text {ns }}$ non-significant. 
In present study, the grain yield of ridge sown wheat was improved by enhancing the seed rate. The increase in grain yield due to increase in seed rate was associated with enhanced number of productive tillers per $\mathrm{m}^{2}$ although average number of tillers per plant, number of grains per spike and grain weight was decreased, as compared to low seed rate (Tables 3 and 4). The increase in number of tillers per $\mathrm{m}^{2}$ due to higher seed rate was mainly associated with higher number of plants per $\mathrm{m}^{2}$ (emergence count) as it was also evident from the fact that the average number of tillers per plant was decreased, as compared to low seed rate (Table 3; Tahir et al., 2019). Moreover, it has been observed that increase in plant population due to increase in seed rate results in decrease in number of grains per spike and grain weight due to competition among plants for available resources (Faris and Pauw, 1980; Iqbal et al., 2010; Isidro-Sánchez et al., 2017). Similar increase in emergence, number of tillers per $\mathrm{m}^{2}$ and grain yield while decrease in spike length, spikelets per spike, grains per spike and grain weight in response to higher seed rate has been reported by Sarker et al. (2009). Similarly, Chauhdary et al. (2016) reported that higher seed rate $\left(160 \mathrm{~kg} \mathrm{ha}{ }^{-1}\right)$ increased the number of tillers per $\mathrm{m}^{2}$ and grain yield of bed planted wheat while decreased number of grains and grain weight, as compared to low seed rates (100 and $130 \mathrm{~kg} \mathrm{ha}^{-1}$ ).

In present study, there was no significant interaction between seed rate and varieties of ridge sown wheat; however, different varieties performed differently regarding yield and yield attributes (Tables 3 and 4). However, Laghari et al. (2011) reported that varieties had significant interaction with seed rate and different varieties responded differently to varying seed rates. In present study, highest grain yield and related attributes were recorded by Faisalabad-08 and it was followed by Galaxy-13, whereas Punjab-11 exhibited the lowest yield and related attributes during all the years (Tables 3 and 4). The maximum yield of Faisalabad-08 was associated with higher number of productive tillers per $\mathrm{m}^{2}$, grains per spike and 1000-grain weight during all the years despite of different climatic conditions during different years (Tables 3 and 4). The difference in yield and yield attributes of different varieties might be associated with differential genetic potential as well as ability to adapt to different environmental conditions (Zecevic et al., 2014; Isidro-Sánchez et al., 2017). Moreover, sowing method has been observed to affect the yield performance of different varieties of wheat (Wang et al., 2004). Kiliç (2010) reported that different varieties performed differently pertaining to yield and related traits in response to sowing method i.e. Sarıçanak-98 performed better with bed planting while Aydın-93 with flat planting method.

The grain yield of ridge sown wheat varieties was influenced by variation in seed rate and it was related to variation in different yield attributes (Tables 3, 4 and 5). The correlation analysis revealed that grain yield of different varieties of ridge sown wheat had significant positive relationship with number of tillers per $\mathrm{m}^{2}(\mathrm{p}<0.001, \mathrm{p}<0.001, \mathrm{p}<0.1)$ during all years, while significant positive relation with 1000 -grain weight $(p<0.001)$ and negative relation with number of grains per spike ( $p<0.001)$ during 2014-15 and 2015-16, respectively, under the influence of different seed rates. On the other hand, the number of tillers per $\mathrm{m}^{2}$ had significant negative relationship with number of grains per spike $(\mathrm{p}<0.05, \mathrm{p}<0.1)$ during 2015-16 and 2016-17, while positive relationship with 1000-grain weight ( $\mathrm{p}<0.05$ ) during 2014-15. Nonetheless, there was non-significant relationship between number of grains per spike and 1000-grain weight of wheat varieties in response to variation in seed rate, during all years (Table 5).

In present study, the grain yield was positively correlated with number of tillers per $\mathrm{m}^{2}$ during all the years; however, positively correlated with 1000-grain weight and negatively with number of grains per spike during 2014-16 and 2015-16, respectively (Table 5). The positive relationship of yield with tillers was associated with increase in plant population due to increase in seed rate (Table 3 ). However, negative relationship of yield with number of grains per spike was due to decrease in number of grains per spike with increase in plant population and increase in yield due to increased tillers per unit area (Tables 3 and 4). Yield and 1000-grain weight were positively correlated during first year of study which was attributed to increase in grain weight despite of increase in plant population; however, this was only during 2014-15 (Table 4). In addition, negative relationship of number of tillers with grains per spike indicated that increase in competition among tillers for available plant resources (Table 5). Furthermore, these relationships indicated that number of tillers per unit area is the main determinant of grain yield in response to seed rate. Previous studies have reported 
similar relationships between yield and related attributes (Spink et al., 2000; Lloveras et al., 2004; Guberac et al., 2005; Lithourgidis et al., 2006; Ozturk et al., 2006).

\section{Conclusions and Recommendations}

The grain yield of ridge sown wheat varieties was improved by increase in seed rate from $125 \mathrm{~kg} \mathrm{ha}^{-1}$ to $150 \mathrm{~kg} \mathrm{ha}^{-1}$ and variety Faisalabad-08 performed better among all varieties. Increasing the seed rate resulted in increase in number of tillers per unit area and decrease in other yield attributes. In conclusion, increase in seed rate improved the grain yield of ridge sown wheat by increasing the number of productive tillers per unit area and could be exploited to improve the wheat productivity.

\section{Author's Contributions}

Javed Iqbal conducted experiment and collected data. Ali Zohaib performed statistical data analysis, prepared the write up and did overall management of article. Muzzammil Hussain supervised the study and gave technical input at every step. Adnan Bashir managed crop in field. Muhammad Hamza helped in conclusion. Wardah Muzaffer collected literature. Muhammad Tahir Latif helped in data analysis. Naeem Faisal helped in data collection.

\section{Conflict of interest}

The authors declare that there is no conflict of interests regarding the publication of this article.

\section{References}

Ali, M., L. Ali, M.Q. Waqar and M.A. Ali. 2012. Bed planting: A new crop establishment method for wheat (Triticum aestivum L.) in cotton-wheat cropping system of Southern Punjab. Int. J. Agric. Appl. Sci. 4(1): 8-14.

Arduini, I., A. Masoni, L. Ercoli and M. Mariotti. 2006. Grain yield, and dry matter and nitrogen accumulation and remobilization in durum wheat as affected by variety and seeding rate. Eur. J. Agron. 25(4): 309-318. https://doi. org/10.1016/j.eja.2006.06.009

Belete, F., N. Dechassa, A. Molla and T. Tana. 2018. Effect of nitrogen fertilizer rates on grain yield and nitrogen uptake and use efficiency of bread wheat (Triticum aestivum L.) varieties on the
Vertisols of central highlands of Ethiopia. Agric. Food Secur. 7(1): 78. https://doi.org/10.1186/ s40066-018-0231-z

Chauhdary, J.N., U.D. Khan, S.H.H. Shah, M.A. Shahid and M. Arsalan. 2016. Effect of sowing methods and seed rates on wheat yield and water productivity. Qual. Assur. Saf. Crops Foods. 8(2): 267-272. https://doi.org/10.3920/ QAS2015.0685

Ciha, A.J., 1983. Seeding rate and seeding date effects on spring seeded small grain cultivars. Agron. J., 75(5): 795-799. https://doi. org/10.2134/agronj1983.00021962007500050 $016 \mathrm{x}$

Ehsanullah, M.A. Shahzad, S.A. Anjum, A.Zohaib, M. Ishfaq and E.A. Warraich. 2017. Effect of different sowing methods and planting densities on growth, yield, fiber quality and economic efficacy of cotton. Pak. J. Agric. Res. 30(1):212-219.

Faris, D.G. and R.M. De Pauw. 1980. Effect of seeding rate on growth and yield of three spring wheat cultivars. Field Crops Res. 3: 289-301. https://doi.org/10.1016/0378-4290(80)900362

Fischer, R.A., I.M. Aguilar, R.O. Maurer and S.A. Rivas. 1976. Density and row spacing effects on irrigated short wheats at low latitude. J. Agric. Sci. 87(1): 137-147. https://doi.org/10.1017/ S0021859600026691

Guberac, V., S. Maric, M. Bede, J. Kovacevic, G. Drezner, A. Lalic, M. Josipovic, M. Krizmanic, T. Juric and D. Kis. 2005. Grain yield of new Croatian winter wheat cultivars in correlation with sowing rate. Cereal Res. Commun. 33(4): 777-784.

https://doi.org/10.1556/ CRC.33.2005.2-3.148

Hussain, I., A. Ali, A. Ahmed, H. Nasrullah, S. Iqbal, A.M. Aulakh, J. Akhter and G. Ahmed. 2018. Impact of ridge-furrow planting in Pakistan: empirical evidence from the farmers field. Int. J. Agron. 2018: 3798037. https://doi. org/10.1155/2018/3798037

Hussain, M., M.M.Q. Baig, M.F. Iqbal, M.Q. Waqar, A. Bashir and M.A. Ali. 2015. Ridge sowing technique: A new crop establishment technique for wheat in rice-wheat cropping system of northern Punjab. Int. J. Adv. Multi. Res. 2(4): 14-18.

Iqbal, N., N. Akbar, M. Ali, M. Sattar and L. Ali. 2010. Effect of seed rate and row spacing on 
yield and yield components of wheat (Triticum aestivum L.). J. Agric. Res. 48(2): 151-157.

Isidro-Sánchez, J., B. Perry, A.K. Singh, H. Wang, R.M. DePauw, C.J. Pozniak, B.L. Beres, E.N. Johnson and R.D. Cuthbert. 2017. Effects of seeding rate on durum crop production and physiological responses. Agron. J. 109(5): 1981-1990. https://doi.org/10.2134/ agronj2016.09.0527

Joseph, K.D.S.M., M.M. Alley, D.E. Brann and W.D. Gravelle. 1985. Row spacing and seeding rate effects on yield and yield components of soft red winter wheat. Agron. J. 77(2): 211-214.

Kabir, N.A.M.E., A.R. Khan, M.A. Islam and M.R. Haque. 2009. Effect of seed rate and irrigation level on the performance of wheat cv. Gourab. J. Bang. Agric. Univ. 7(1): 47-52. https://doi. org/10.3329/jbau.v7i1.4797

Khan, I.A., J. Bakht, W.A. Shah, N. Khan and I. Ullah. 2002. Effect of Seed Rate on the Yield and Yield Components of Wheat under Irrigated Conditions of Peshawar. Asian J. Plant Sci. 1: 513-515. https://doi.org/10.3923/ ajps.2002.513.515

Kiliç, H., 2010. The effect of planting methods on yield and yield components of irrigated spring durum wheat varieties. Sci. Res. Essays 5(20): 3063-3069.

Krause, U., H.J. Koch and B. Maerlaender. 2009. Soil properties effecting yield formation in sugar beet under ridge and flat cultivation. Eur. J. Agron. 31(1): 20-28. https://doi.org/10.1016/j. eja.2009.02.002

Laghari, G.M., F.C. Oad, S. Tunio, Q. Chachar, A.W. Gandahi, M.H. Siddiqui, S.W.U. Hassan and A. Ali. 2011. Growth and yield attributes of wheat at different seed rates. Sarhad J. Agric. 27(2): 177-183.

Lithourgidis, A.S., K.V. Dhima, C.A. Damalas, I.B. Vasilakoglou and I.G. Eleftherohorinos. 2006. Tillage effects on wheat emergence and yield at varying seeding rates, and on labor and fuel consumption. Crop Sci. 46(3): 1187-1192. https://doi.org/10.2135/cropsci2005.09-0321

Lloveras, J., J. Manent, J. Viudas, A. López and P. Santiveri. 2004. Seeding rate influence on yield and yield components of irrigated winter wheat in a Mediterranean climate. Agron. J. 96(3): 1258-1265. https://doi.org/10.2134/ agronj2004.1258

Nakano, H. and S. Morita. 2009. Effects of seeding rate and nitrogen application rate on grain yield and protein content of the bread wheat cultivar 'Minaminokaori'in Southwestern Japan. Plant Prod. Sci. 12(1): 109-115. https:// doi.org/10.1626/pps.12.109

Nizamani, G.S., S. Tunio, U.A. Buriro and M.I. Keerio. 2014. Influence of different seed rates on yield contributing traits in wheat varieties. J. Plant Sci. 2(5): 232-236. https:// doi.org/10.11648/j.jps.20140205.23

Otteson, B.N., M. Mergoum and J.K. Ransom. 2007. Seeding Rate and Nitrogen Management Effects on Spring Wheat Yield and Yield Components. Agron. J. 99: 1615-1621. https:// doi.org/10.2134/agronj2007.0002

Ozturk, A., O. Caglar and S. Bulut. 2006. Growth and yield response of facultative wheat to winter sowing, freezing sowing and spring sowing at different seeding rates. J. Agron. Crop Sci. 192: 10-16. https://doi.org/10.1111/j.1439037X.2006.00187.x

Park, S.E., L.R. Benjamin and A.R. Watkinson. 2003. The theory and application of plant competition models: An agronomic perspective. Ann. Bot. 92(6): 741-748. https://doi. org/10.1093/aob/mcg204

Rasool, T., A. Zohaib, R. Ahmad, T. Abbas, T. Tabassum and M.A. Nadeem. 2017. Forage yield and quality in pearl millet-sesbania intercropping system under various geometrical patterns. Pak. J. Agric. Res. 30(1): 75-84.

Read, D.W.L. and F.G. Warder. 1982. Wheat and barley responses to rates of seeding and fertilizer in southwestern Saskatchewan. Agron. J. 74(1): 33-36. https://doi.org/10.2134/agronj1982.00 021962007400010011x

Sarker,M.A.Z.,P.K.Malaker,M.Bodruzzaman and N.C.D. Barma. 2009. Effect of management and seed rate on the performance of wheat varieties with varying seed sizes. Bang. J. Agric. Res. 34(3): 481-492. https://doi.org/10.3329/ bjar.v34i3.3975

Spink, J.H., T. Semere, D.L. Spares, J.M. Whaley, M.J. Foulkes, R.W. Clare and R.K. Scott. 2000. Effect of sowing date on the optimum plant density of winter wheat. Ann. Appl. Biol., 137(2): 179-188. https://doi. org/10.1111/j.1744-7348.2000.tb00049.x

Staggenborg, S.A., D.A. Whitney, D.L. Fjell, and J.P. Shroyer. 2003. Seeding and nitrogen rates required to optimize winter wheat yields 
following grain sorghum and soybean. Agron.

J. 95: 253-259. https://doi.org/10.2134/ agronj2003.0253

Steel, R.G.D., J.H. Torrie and D.A. Deekey. 1997. Principles and procedures of statistics: a biometrical approach, $3^{\text {rd }} \mathrm{Ed}$. McGraw Hill Book Co. Inc. New York. pp. 400-428.

Stephen, R.C., D.J. Saville and E.G. Drewitt. 2005. Effects of wheat seed rate and fertiliser nitrogen application practices on populations, grain yield components and grain yields of wheat. N. Z. J. Crop Hortic. Sci. 33(2): 125-138. https://doi.or $\mathrm{g} / 10.1080 / 01140671.2005 .9514341$

Tahir, S., A. Ahmad, T. Khaliq and M.J.M. Cheema. 2019. Evaluating the Impact of Seed Rate and Sowing Dates on Wheat Productivity in SemiArid Environment. Int. J. Agric. Biol. 22(1): 57-64.

Tapley, M., B.V. Ortiz, E. van Santen, K.S. Balkcom, P. Mask and D.B. Weaver. 2013. Location, seeding date, and variety interactions on winter wheat yield in southeastern United States. Agron. J. 105(2): 509-518. https://doi. org/10.2134/agronj2012.0379

Wang, F., X. Wang and S. Ken. 2004. Comparison of conventional, flood irrigated, flat planting with furrow irrigated, raised bed planting for winter wheat in China. Field Crops Res. 87(1): 35-42. https://doi.org/10.1016/j.fcr.2003.09.003

Zecevic, V., J. Boskovic, D. Knezevic and D. Micanovic. 2014. Effect of seeding rate on grain quality of winter wheat. Chilean J. Agric. Res. 74(1): 23-28. https://doi.org/10.4067/ S0718-58392014000100004

Zohaib, A., S. Yousaf, S.A. Anjum, T. Tabassum, T. Abbas, W. Muzaffar and W. Ikram. 2019. Growth, allometry and dry matter yield of soybean genotypes in response to seed inoculation with plant growth promoting rhizobacteria. Pak. J. Agric. Res. 32(1): 102-109. https://doi.org/10.17582/journal. pjar/2019/32.1.102.109

Zohaib, A., T. Tabassum, A. Jabbar, S.A. Anjum, T. Abbas, A. Mehmood, S. Irshad, M. Kashif, M. Nawaz, N. Farooq, I.R. Nasir, T. Rasool, M. Nadeem and R. Ahmad. 2018. Effect of plant density, boron nutrition and growth regulation on seed mass, emergence and offspring growth plasticity in cotton. Sci. Rep. 8: 7953. https:// doi.org/10.1038/s41598-018-28825-9 